\title{
From Unfree Work to Working for Free: Labor, Aid, and Gender in the Nigerien Sahel, 1930-2000
}

\author{
Benedetta Rossi \\ University of Birmingham
}

\begin{abstract}
This article focuses on the consequences of twentieth-century developmentalism for labor practices in the Nigerien Sahel under French rule and in the postindependence period. It examines labor regime transformations at the desert's edge; the ways in which state-led developmentalism influenced labor relations; and gender disparities in the history of emancipation from slavery. Following the abolition of forced labor in 1946, the rhetoric of human investment was used to promote the "voluntary" participation of workers in colonial development initiatives. This continued under Niger's independent governments. Seyni Kountché's dictatorship relabeled Niger "Development Society" and mobilized Nigeriens' "voluntary" work in development projects. Concurrently, drought in the Sahel attracted unprecedented levels of international funding. In the Ader region this led to the establishment of a major antidesertification project that paid local labor on a food-for-work basis. Since most men migrated seasonally to West African cities, the majority of workers in the project's worksites were women who welcomed "project work" to avoid destitution. In the name of development, it continued to be possible to mobilize workers without remuneration beyond the cost of a meal.
\end{abstract}

In the 1940s male workers in the Ader region in today's Republic of Niger went from being recruited as forced labor on colonial worksites to being enrolled in colonial development schemes as volunteer participants. ${ }^{1}$ With the abolition of slavery and forced labor, the decreasing viability of coercive recruitment allowed labor migrants to elude both compulsory recruitment and imposed "volunteering" more readily than before. Attracted by prospective higher earnings elsewhere, an ever-growing number of men embarked on a "rural exodus," seeking jobs in West African cities. ${ }^{2}$ But voluntary participation in development was not easily avoided: constructed as moral obligation, strategy for survival, charter for citizenship, and an avenue to international revenues, participation in development became the central practice for the realization of the social contract. This process culminated with Seiny Kountché's totalizing vision of "Development Society."

In 1974 Seyni Kountché seized power. Under his military dictatorship citizenship was redefined in terms of participation in national development. Concurrently, drought in the Sahel attracted unprecedented levels of international funding. In Ader, this conjuncture led to the establishment of a major antidesertification project that paid local labor on a food-for-work basis. Since most men migrated seasonally to West African cities, the majority of workers 
in the project's worksites were women who welcomed "project work" to avoid hunger and extreme destitution. In the name of development, it continued to be possible to mobilize workers without remuneration beyond the cost of a meal. That these workers were mainly women of slave descent was not a random contingency. Gender ideologies limited these women's options, leaving them to compete over occupations shunned by men of their status.

This article examines three processes: labor regime transformations at the desert's edge; the specific ways in which state-led developmentalism influenced labor relations; and gender disparities in the history of emancipation from slavery. In Ader these three processes were inextricably intertwined. As Frederick Cooper has shown, in the 1940s the idea of development enabled European powers to reassert the legitimacy of colonial government when the ideological foundations of imperial rule began to crumble. ${ }^{3}$ The geopolitical implications of the developmentalist turn did not go unnoticed: already in the 1960s, Western developmentalism was criticized as neocolonial exploitation. ${ }^{4}$ But commentators also emphasized the versatility of the development concept: African elites and commoners were able to make claims in the name of development and turn developmentalism to their advantage. ${ }^{5}$ This much has been documented extensively. The question addressed in this article is more specific: how did developmentalism influence labor relations and labor management? Circumstances differed across African regions.

In the Nigerien Sahara-Sahel returns to labor are both lower and less predictable than in more productive and technologically developed areas. The desert poses specific challenges to both potential employers and employees. Harvest failure, pest attacks, and the vulnerability of pastures put a premium on diversification and mobility. ${ }^{6}$ In addition to these environmental limitations, the high cost of transport and infrastructure provision and maintenance hinders the development of cash crops that would enable employers to offer wages high enough to offset a worker's preference for migration. ${ }^{7}$ Incentives to move are high. When slavery and forced labor were legal, employers resorted to coercion to force people to work for them in enterprises unlikely to generate substantial profits. The colonial administration forcibly enrolled locals, mostly slave descendants, in its few and unimpressive desert-edge worksites. When forced labor was declared illegal, development offered a rationale for imposing "voluntary" participation in works that would allegedly benefit local communities. This discursive turn took a special inflection in the Sahara-Sahel.

Life at the desert's edge is profoundly conditioned by environmental necessity. ${ }^{8}$ But the Sahel is also culturally constructed, and has been for centuries. It featured in the moral geographies of Arabic travelers as the "shore" that bordered the absolute desert, partaking in religiously and racially colored models of the world. ${ }^{9}$ Ideas about Tuareg "lords of the desert" influenced military intervention and colonial policy vis-à-vis Sahelian inhabitants and pervaded the latter's sense of self. ${ }^{10}$ At least since the 1970 s, a new discourse about the Sahel has been portraying it as coterminous with famine, poverty, and crisis. Vincent Bonnecase analyzed the major discursive reconfiguration that redefined 
the Sahel in terms of poverty. ${ }^{11}$ Gregory Mann described this reconfiguration as a transition "from empires to NGOs," one that "opened a political space of imported initiatives, controlled distribution, and constrained sovereignty," marking a transition from state-centered developmentalism to nongovernmentality. ${ }^{12}$ He showed how European, American, and African political and epistemic networks coproduced the discourse of Sahelian crisis. Other authors denounced the power inequalities that lie behind multilateral appraisals of world hunger. ${ }^{13}$

The literature on the aid industry surrounding visions of Sahelian crisis does not focus on labor. This article aims to fill this gap. It examines the consequences of the developmentalist turn in postwar colonial governance for the mobilization of labor in the Tahoua region (also known as "Ader") of the Nigerien Sahel. Here survival-or success, as the case may be-depends upon overcoming challenges posed by the adjoining desert. ${ }^{14}$ Developmentalism at the desert's edge provided new discursive means for articulating demands upon local labor. Since independence, these demands have been framed in the language of the antidesertification narrative. Developmentalists in Ader sought labor from workers who needed to diversify risk and were pulled relentlessly toward places where work yielded higher rewards. These dynamics were neither gender- nor status-blind. ${ }^{15}$ Men and women, freeborn and slave descendants, did not have the same opportunities to access capital, be paid a wage, and move autonomously. Because for different people "everything is not equally possible or impossible," 16 economic and social emancipation were easier for men than for women.

\section{From Slavery to Aid: The Rise of Developmentalist Governance}

In the 1920s and 1930s the League of Nations and the International Labor Organization put pressure on colonial powers to end slavery and forced labor in their African territories. Reports written by successive district officers based in the Cercle of Tahoua showed that slavery continued to exist well into the 1940s. Persons of slave descent denounced masters who had sold their relatives and testified against them in colonial tribunals. ${ }^{17}$ Trafficked slaves sometimes were found and reintegrated into their families. The majority of slave descendants distanced themselves gradually from their impoverished former owners and started working on their own account. ${ }^{18}$ In 1946 the abolition of forced labor resulted in intensified intolerance for legacies of slavery. ${ }^{19}$ Even if slavery and the slave trade still existed on a small scale, they were mentioned rarely in official reports to avoid international scandals. French administrators strove to introduce labor contracts meant to regulate labor relations between natives. ${ }^{20}$ In July and August of 1947 Captain Reeb, commanding the Nomad Subdivision of Tahoua, ${ }^{21}$ developed pro forma contracts for the regulation of indigenous labor. ${ }^{22}$ But Ader's herders and farmers, mostly illiterate, never adopted these contracts. ${ }^{23}$ In 1948 a report of Tahoua's Commandant de 
Cercle still argued that the endurance of slavery was the region's fundamental problem. $^{24}$

If eradicating indigenous slavery proved difficult, paying adequate wages to former forced labor in colonial projects proved impossible. Developmentalism made cheap labor available after the abolition of forced labor. In the mid-1930s, the first initiatives of mise en valeur were generated by the interaction between local administration and rural populations. ${ }^{25}$ Commandant de Cercle Adelard de Loppinot was the first to advocate that France moderate the extractive nature of its rule and instead invest in economic development. He suggested building dams that would increase agricultural yields and thus contribute to food security in the cercle. The war in Europe slowed down progress on these initiatives until the early 1940s. In a report written in 1943 , Commandant Brouin recommended building hydraulic structures aimed at increasing agricultural productivity near the village of Toudounni, around the Lake of Aduna, and on the lands surrounding the Keita Lake (Fig. 1). ${ }^{26}$ The aim of these projects was to support the local farming technique of cultivating lakeshores progressively uncovered by waters retiring by evaporation in the months following the rains. A floodgate and an outlet would allow farmers to regulate the retreat of waters from farming lands at the right moment in the farming cycle (November-December), irrespective of annual variations in rainfall and evapotranspiration. Brouin thought that these interventions had the potential to increase production substantially but feared that labor shortages due to seasonal migration would hinder future agricultural development.

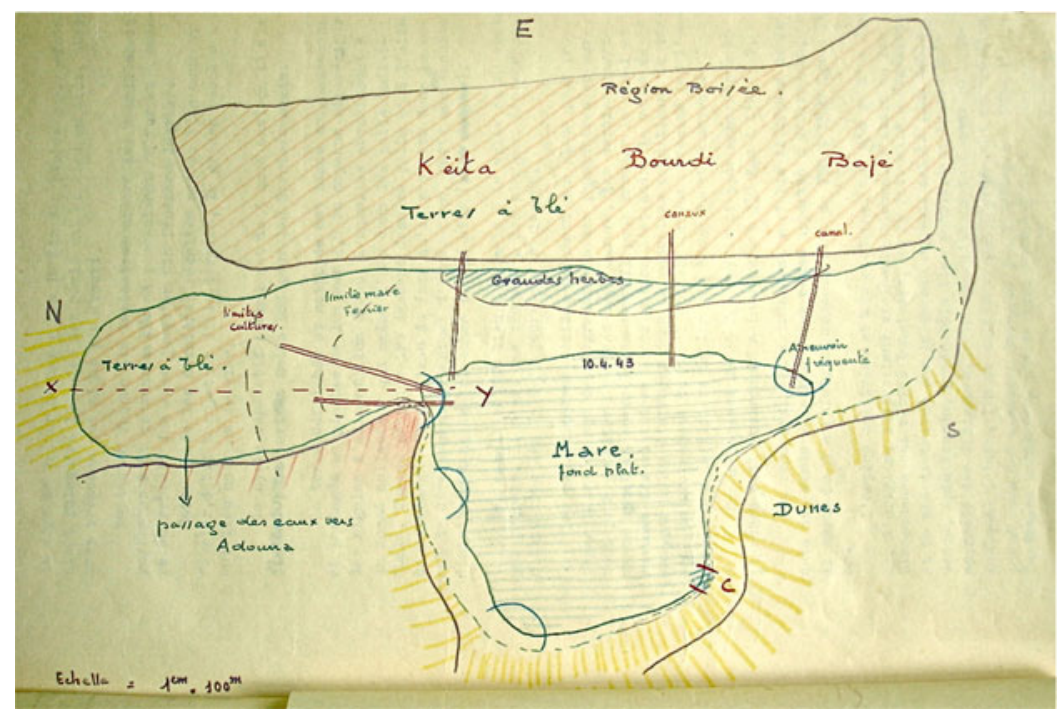

Figure 1. Brouin's 1943 study of the Keita lake. 
The Brazzaville Conference of 1944 led to an expansion of metropolitan engagement in the development of France's colonies. ${ }^{27}$ In the spring of 1946, the Houphouët-Boigny Law abolished forced labor; and the first Lamine Guèye Law extended French citizenship to former colonial subjects and abolished the Code de l'Indigénat. Also in 1946, France established the Fonds d'Investissements pour le Développement Économique et Social (FIDES), which dispensed development capital to its colonial territories. After the abolition of forced labor French administrators who had, until then, relied on various forms of compulsory labor faced the dilemma of having to pay local workers. This dilemma was solved through the introduction of developmentalist rationales that recast indigenous labor as "human investment" - that is, labor contributed voluntarily by the "beneficiaries" of development projects.

The mid-1940s marked a pervasive discursive reorientation. The administrators' regular supervision tours went from focusing on political intelligence to assessing the agricultural potential of different types of lands in the cercle. Studies of local farming practices were followed by recommendations for improvements and the introduction of new crops. ${ }^{28}$ The prewar obsession with the loyalty of chiefs and colonial subjects was replaced by micromanagement of rural production and trade. The slavery question, too, was put aside. Elites, commoners, and ex-slaves were conflated into the single category of "peasants," whose primary feature consisted in being developable, like land and water resources.

By 1955, most of the large temporary and permanent lakes in the Cercle of Tahoua had been surveyed with a view to their potential use for irrigated farming. ${ }^{29}$ At independence, in 1960, Niger remained largely dependent on France financially. The FIDES, renamed Fond d'Aide et Coopération (FAC), financed the implementation of national development plans, whose main authors were French consultants. National staff replaced French commandants on the ground, but French "experts" wrote applications for French financial assistance. Thus, French staff went from occupying administrative roles to holding technical positions. Their functions remained essentially political, though, as they oversaw the allocation of funds to particular activities, areas, and groups.

Studies and pilot projects were realized in the period from 1961 to 1965 , corresponding to Niger's Three-Year $\operatorname{Plan}^{30}$ and to the first years of the Ten-Year Perspectives (Perspectives Décennales). The government defined national irrigation policies; the Ministère de l'Economie Rurale was responsible for their application, assisted by the Comité Permanent du Développement Rural. The Service des Aménagements Hydro-Agricoles, a specialized organ of the UNCC (Union Nigérienne de Crédit et de Coopération), oversaw the management of hydroagricultural projects. It was headed by three hydraulic engineers from the Food and Agriculture Organization of the UN (FAO). ${ }^{31}$ Most projects were coordinated by the French society SOGETHA (Société Générale des Techniques Hydro-Agricoles) and aimed at increasing agricultural productivity. ${ }^{32}$ These projects required labor for reforestation, antierosion 
works, and for the construction of hydraulic structures (Fig. 2). In 1966, two conventions were signed for a regional development program targeting the Ader Doutchi Majiya region coordinated by the Secrétariat des Missions d'Urbanisme et d'Habitat (SMUH) with a planned duration of fifteen to twenty years. ${ }^{33}$

Ader figured prominently in Niger's first Three-Year Program under the new name "Ader Doutchi Majiya." ${ }^{34}$ A 1964 policy document entitled Réflexions sur les Options Préalables à la Mise en Valeur de l'Ader Doutchi Majiya defined the Ader Doutchi Majiya as a "voluntary region" deriving unity not from historical or cultural criteria, but primarily from its alleged potential to be developed. ${ }^{35}$ It described the Ader Doutchi Majiya as an "island of lesser underdevelopment in the middle of surrounding regions." ${ }^{36}$ Its development potential was allegedly inscribed in its demography and geography: It contained a "dense Hausaphone farming population (more than 20 inhabitants per square kilometre)" and "lands of exceptional fertility, for this country, as well as water resources. ${ }^{\prime 37}$ These characteristics were seen as requiring specific interventions managed by new institutions. Northern Ader's two main areas of intensified development action, also known as "perimeters," surrounded the dams of Keita and Ibohamane, and exploited the irrigation possibilities created by these hydraulic structures. "Perimeters" were divided into irrigated plots farmed by people living in surrounding villages. Willingly or unwillingly, villagers who owned lands in these areas had to participate in the new developmentalist regime.

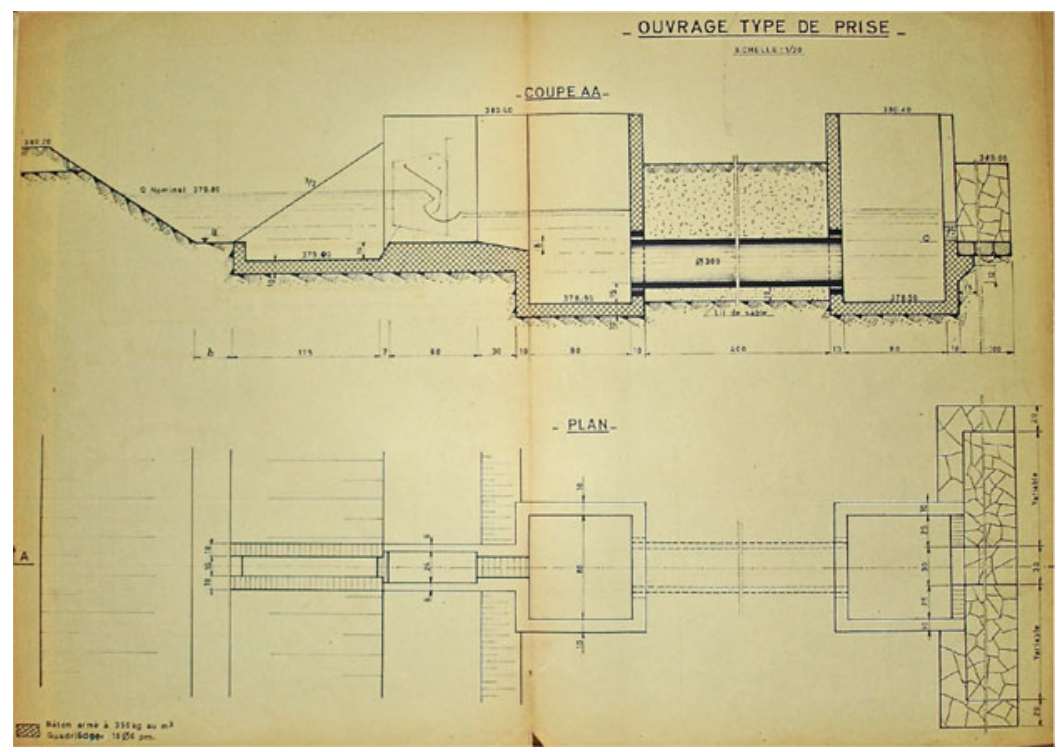

Figure 2. Technical drawing of hydraulic structure, 1966. 


\section{Labor as "Human Investment"}

The Réflexions sur les Options Préalables noted that the development plans envisaged for the Ader Doutchi Majiya could have been realized by paying local labor, as had been the case in a few pilot schemes. ${ }^{38}$ This option, it argued, would have yielded the best results; however, the costs would have been prohibitive, and the program would have failed to take advantage of the seasonal unemployment of local farmers outside the agricultural season. ${ }^{39}$ The report argued that locals had to be led to realize that they needed these interventions. Such need would have to be so pressing as to overcome people's rational inclination to sell their labor at higher rates of pay elsewhere: "Naturally it is necessary for users to feel the need for this intervention (role of rural extensionists); to have the technical capability (role of the technical services) and the materials needed to realize [the works]."40

The process envisaged here would begin with the intervention of the "rural extension officer, leading relatively quickly to the formulation of a demand by the farmers concerned." 41 Hence, the rural extension officer's function was to make the process appear as driven by the demand of local communities. But in fact the intervention had already been planned by the actors who were going to manage it. ${ }^{42} \mathrm{~A}$ footnote reveals that it was clear to the planners that local interest in this type of intervention was tied primarily to the employment opportunities that they generated:

Many applications have already been received. But these applications are based on the locals' assumption that the project will open worksites employing paid labor, rather than implement development actions aimed at improving their lands through their own work, the benefits of which will become visible only at the harvest. ${ }^{43}$

In training delivered to regional development staff on Niger's second National Development Plan, the session on "Human resources and equipment" set out the need to rely on the voluntary contribution of local labor: "In a capital-poor country [like Niger] it is necessary to encourage as much as possible human investment, indispensable before the immensity of the tasks and the weakness of interior financial means." 44

Unsurprisingly, rural villagers faced with recurrent food scarcity and lack of income did not welcome these arguments. It was all very well to invest in agricultural productivity; but these plans paid normal salaries to all those involved in their realization except local villagers, who were also the poorest and most vulnerable to famine. In these circumstances, migration continued to prove an obstacle to the recruitment of voluntary workers. The minutes of the meeting of the Committee of Ader Doutchi Majiya on July 22, 1965, commented sarcastically, "There is a direct competition between "free" development worksites [aménagements "gratuits"] and paid worksites, that is, temporary migration." 45 
Donors expected "beneficiaries" to contribute to development actions in their regions as a condition for the release of funds. Therefore funding applications mentioned the "availability" of local populations. However, these demands were not written by the "beneficiaries" but by consultants and developers who benefited from these operations in the form of salaries, consultancy fees, and funding made available to the institutions they worked for. Funding applications did not hesitate to volunteer the labor of "beneficiaries": "There are signs already that manifest a conscientisation [prise de conscience] in several domains ... The country [le pays] does not merely wish to receive aid, but ... it is ready to contribute directly to its own development through its own labor."46 However, much to the chagrin of development bureaucrats, local workers refused to be involved unless they obtained some remuneration. In the end, a midway arrangement compensated workers by paying them roughly half the standard wage for one day of field labor:

When we launched this initiative, we had intended that the community would carry out the totality of non-specialized works without remuneration; but we had forgotten the need for cash that [locals] usually meet through seasonal migration. The difficulties of the 1967-1968 season, discussed in the general report of the rural development extension, were due essentially to the departure of substantial numbers of migrants which destabilized operations on the worksites. Consequently in 1968-1969 it was decided to compensate villagers in cash for their work. The amount was calculated to roughly match the earnings of 3 to 4 months of migrant work, that is, about 4,000-5,000 francs. Preliminary evaluations had shown that by paying workers a half-salary (un démi-salaire)-and hence retaining half of their labor as human investment-the cost of labor for one hectare of soil restoration varied between 8,000 and 10,000 francs. In conditions of average difficulty and average slope steepness, one meter of anti-erosion bunds (banquette) costs 25 francs. $^{47}$

\section{Struggles Over Land and Labor in the Ibohamane Perimeter}

The Ibohamane perimeter obtained FAC funding in $1967 .{ }^{48}$ French specialists in rural development had made a census of the original owners of lands in the perimeter. Then, they redistributed plots according to criteria that fitted with their notions of development. One of these criteria was family size. Some large owners with small families lost land. The redistribution of lands that followed the installation of the Ibohamane perimeter did not always respect the size of farms that had existed before the planned interventions. Frustration has lingered to the present day:

The whites came with their papers, asked who had what, people answered whatever was in their interest to say, whites wrote it down, and that was it ... some peasants were not brave enough to argue with powerful people at the meetings. The 
next thing they knew, they were told their fields were half the size they used to be. A French man called Guy came to Ibohamane - the land was split into parcels, redistributed, and he said: one day you will benefit from this. ${ }^{49}$

The valley of Ibohamane had eroded rapidly since the end of the 1950s. Comparison of aerial photographs taken in 1964, 1965, and 1967 showed a progressive loss of vegetation and deepening of river beds, leading to the violent channeling of rains downstream, rather than spreading into valleys and fields. ${ }^{50}$ The main operation foreseen by the development plan of 1966 consisted in the creation of an irrigated perimeter of 750 hectares around the recently built dam of Ibohamane. ${ }^{51}$ New seed varieties were tried, and plow oxen were tentatively - and unsuccessfully - introduced; regular meetings were held on the last Thursday of each month, Thursday being market day in Ibohamane. Ibohamane's farmers perceived this new regime as burdensome. It encroached on their time, introduced new costs and liabilities, and imposed new farming methods that may have increased production on the perimeter plots but failed to take into account people's need to diversify livelihoods.

Extension officers sought to ensure that tight farming schedules and newly introduced practices (such as double hoeing) were followed by all the members of the Ibohamane perimeter. Invariably, they were not. Minutes of meetings reveal the frustration of French experts vis-à-vis what they saw as the irrational resistance of local peasants and the frustration of participating villagers, especially senior farmers, doubtful of the efficacy of the new methods.

Meetings of the local development committee often resulted in threats and expropriations unless farmers complied with the new requirements. For example, at a meeting on July 25, 1968, of Ibohamane's COLOMIVAL (Comité Local pour la Mise en Valeur de la Plaine d'Ibohamane), Mr. Chareton, head of Tahoua's agricultural services division, read to the assembled farmers the dates and locations scheduled for the sowing, resowing, and hoeing of cotton and sorghum. He was informed that the elderly village chief of Tagorom refused to hoe his field. The chief was asked to justify his resistance. He explained that he had arranged some rituals to propitiate the harvest and hired labor to ensure a successful cotton harvest, but his harvest had died and he had to sow again. He was waiting for the new harvest. And it had always been his habit to hoe once, not twice. Sambo Betty, head of Keita's agricultural extension service, told the elder that if he was incapable of farming his land appropriately, he should have rented it out to someone else. Mr. Ousmane Bako cited a statement of the vice prefect at a previous meeting: "In the future we shall make no attempt to reconcile misunderstandings that obstruct Ibohamane's development: we will impose sanctions against offenders." The meeting's minutes concluded that "[a]fter long discussions with the old man we established that he was not reasoning properly and one member of his family agreed to take charge of his fields." 52

Reforestation activities and works for the building of hydraulic structures in Ibohamane had been carried out by locals who did not migrate. As noted 
above, in the end these workers had to be paid a low salary, which was nevertheless appreciated more than any other aspect of the intervention. A 1970 survey quoted Ibohamane's village chief: "For us the bad season will start with the departure of the workers and of the enterprise which employs them." As glossed by the author of the report, Ekaney Chimier, the chief meant that "the salaries allowed local villagers to partly overcome the difficulties tied to a poor farming season." Moreover, the company in charge of the construction works had bought gravel from local villagers. The report ends with another quote from the chief of Ibohamane: "We thank Allah that this operation fell in a particularly difficult year. In each one of our families at least one child has been hired to work on the perimeter. And almost three quarters of the gravel that we produced have been sold." 53 What mattered most to local villagers had been the creation of paid employment opportunities. By contrast, the refrain of administrative and donor reports was that "real development" presupposed the "ownership" of development projects by their direct beneficiaries. If, this logic went, they were too poor to pay for these interventions themselves, they ought at least to provide voluntary labor.

The Ibohamane Irrigation Perimeter was located near the large village of Ibohamane in the fertile valley lands that formed the Ibohamane valley. But Ibohamane's rural hinterland consisted mostly of scarcely fertile dry glacis land and rocky hills that supported a growing number of villages and hamlets. These villages were inhabited by a large proportion of poor slave descendants who were still in contact with elites of the former master class, and sometimes with the owners of their parents. With the spread of motorized transport, men from these areas migrated to distant destinations, as distance facilitated social mobility by making them less recognizable as slave descendants. From 1967 to 1970 Ader migrants were paid to fight in the Biafran war; ${ }^{54}$ others traveled north and worked in the mines around Arlit and Agadez and others still went to Abidjan. ${ }^{55}$ These migrants were former nomadic herders who had been settling progressively in small hamlets on marginal lands that had not been farmed in the past. ${ }^{56}$ Through migration, they eluded enrollment in development schemes. In the 1960s and 1970s their villages were not targeted by development activities because they lacked resources worth developing. But following the 1968-1973 Sahel famines new international institutions started targeting these ecologically marginal areas. The perceived need to "fight against desertification" paved the way for the spread of antidesertification projects in the Sahel. ${ }^{57}$ Development worksites reached the remote villages of Tahoua's hinterland.

\section{The Development Society}

On April 15, 1974, Lieutenant Colonel Seyni Kountché, chief of the national army, seized power in a coup d'état, suspending the constitution of 1960, dissolving all political organizations, and delegating full powers to the Supreme Military Council, which he himself headed. For the following fifteen years ${ }^{58}$ 
Niger was under military rule. The coup was promoted as bringing social reform and national renewal. ${ }^{59}$ Four months later, in a programmatic message to the nation delivered on August 3, 1974, Kountché expounded for the first time his ideal of a "Development Society" (Société de Développement). ${ }^{60}$

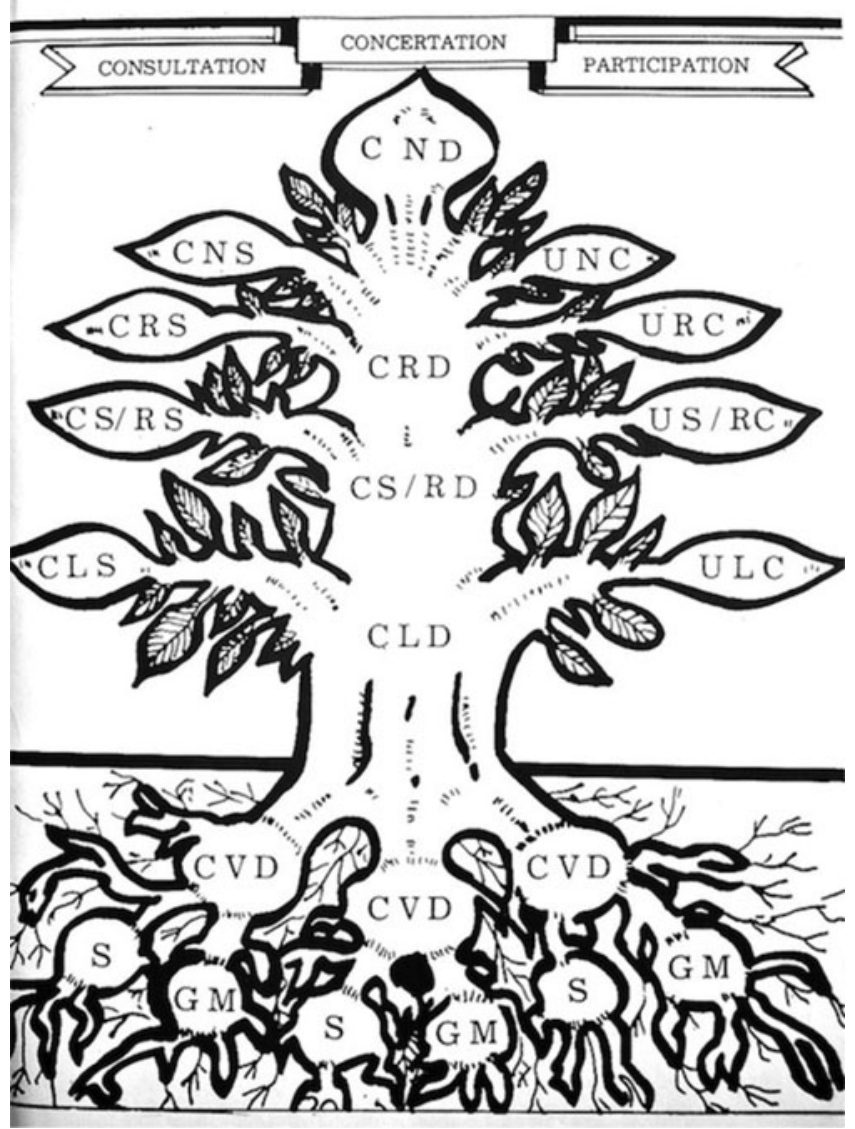

Figure 3. Organigram of Development Society (CND Bulletin, January 1984, No. 1).

Development became the raison d'être of all national institutions and groups. As a result of the work of the National Commission, ${ }^{61}$ by 1982 the structures of the Development Society had been established at all levels: village, canton, subregion (arrondissement), region (département), and the National Council. At each level, development councils comprised representatives of different social constituencies (Fig. 3). Particular emphasis was placed on the "traditional" village-level youth organizations (Hausa: samariya) and on the rural cooperatives, which consisted of farmers organized through the institution of 
the "mutual" (groupement mutualiste villageois). Representatives of these two institutions made up half of the Council's members. The other half included members from ten different socioprofessional associations, among which were the Association of Nigerien Women (Association des Femmes du Niger, AFN) and the Islamic Association of Niger (Association Islamique du Niger, AIN). The Development Society was a totalizing nationalist project, which claimed legitimacy on the basis of popular participation:

I would compare the Development Society to a pyramid, in which the population will express itself from the bottom and organize itself for [development] management at each level. The base of the pyramid will cover the entire territory of the country, organized into development cells. ${ }^{62}$

The Development Society was conceived as an expression of the will of the Nigérien people. This contrasted with the absence of elections. Official statements contrasted Niger's "participatory democracy" to the "Western model of multi-party liberal democracy." 63 "Participatory democracy" would lead to "a profound conversion of mentalities." 64 This transformation would not imply an emulation of Western modernization, but rather follow Nigerien models of development: "The Development Society was born out of the failure of imported development policies, which never truly took into consideration the country's realities." ${ }^{25}$ Yet in spite of this nationalist rhetoric, donor countries and organizations continued to provide both policy frameworks and the financial means to implement these.

The advent of the Development Society marked a major change in how rural populations experienced their relation to the state. Through its populist ideology, the Development Society reached out to Niger's immense countryside, hitherto scarcely exposed to central government. "Voluntary" participation in national reconstruction was imposed. Prefect Mamadou Tandja, future president of Niger, expected the people of Tahoua to volunteer labor to reconstruction efforts: "[P]opular participation will be massive and voluntary." 66 In 1984, the Department of Tahoua hosted 1,015 Village Development Councils; 346 Tribe Development Councils; 82 Local Development Councils; and 8 Sub-Regional Development Councils. The Regional Development Council could call on about thirty members and met every three months. ${ }^{67}$ Activities were regularly organized, down to the village level. Cooperative structures were considerably expanded. In 1984 the Tahoua Department counted 1,671 Groupements Mutualistes; 202 cooperatives (40 of which in pastoral regions), 44 Local Cooperative Unions, and 8 Sub-Regional Cooperative Unions. ${ }^{68}$ However, recurrent assessments reported that in the Tahoua Department "cooperatives exist only nominally." ${ }^{69}$ Communication was hampered by poor road infrastructure. Rural populations failed to participate as fully as expected. $^{70}$

The pace of change increased with the establishment of a major development project, initially called Projet Integré Keita (PIK), later renamed Projet de 
Développement Rural Integré de l'Ader Doutchi Majiya (PDR/ADM), but commonly referred to as "Keita Project." The Keita Project started its activities in 1984. Financed by the Italian Aid Agency and implemented by the FAO, the Project injected external funds, personnel, and expertise into the operation of the Development Society in Tahoua. The president of Tahoua's Regional Development Council in the Project's first phase was, again, Mamadou Tandja. $^{71}$

\section{The Keita Project}

The Project's long-term objectives corresponded to the aims set out in Niger's Five Year Development Plan 1979-1983, namely food self-sufficiency, the establishment of the Development Society, and economic independence. ${ }^{72}$ The Project was meant to work in association with the regional administration. Until the dissolution of the structures of the Development Society, Project and national participatory structures coincided: "The integrated rural development project of Keita has been envisaged to act as technical, logistical, and financial support to the Development Society and its participatory structures in the district of Keita."73

During its first phase (May 1984-June 1991), the Project covered only the District of Keita (approximately 3,200 square kilometers with a population of 156,000 inhabitants at the inception of the project). In its second phase (July 1991-June 1996), operations were extended to the adjacent districts of Bouza and Abalak, and the Project's intervention area reached its maximum extension of 13,000 square kilometers, with about 330,000 inhabitants in 1991. In its third phase (July 1996-June 1999) a further extension toward the southern Majiya Valley was contemplated but never implemented. About 400 villages fell within the project's intervention area. The funds provided by the Italian government amounted to a total of about US\$63.5 million up to the end of 1999. Between 1984 and 2000 the World Food Program contributed 12 million individual food rations, with an estimated value of about US $\$ 17$ million. ${ }^{74}$

The Keita Project was conceived in response to the droughts that hit Ader in the early 1980s, and its principal aim was to fight against desertification. However, in line with its "integrated development" objective, it carried out a broad range of activities. The intervention area was subdivided into Basic Territorial Units, or BTUs, corresponding to subcatchment systems, each with an area of about ten square kilometers. Project activities aimed at soil and water conservation, including antierosion bunds on glacis and plateau lands, reforestation trenches on slopes and rocky hillsides, windbreaks (tree rows) in valleys, dense tree planting along the sides of water courses, and dense tree planting matched to rows of dry millet-stalks to fix dunes. Activities aimed at controlling the hydraulic regime led to the construction of more than 100 dams.

In the first phase, activities were undertaken on the basis of annual programs agreed upon by Keita's Sub-Regional Committee of the Development 
Society (Comité Sous régional de la Société de Développement de Keita) headed by Tandja. Programs were drawn up in consultation with village representatives and in cooperation with departmental technical services (services techniques départementaux). ${ }^{75}$ The main problem was that public funding was not available to pay workers a wage comparable to the earnings they could achieve as migrant workers. The seasonal flow of Ader's labor migrants never stopped, for the same old reasons: enforcing immobility at the desert's edge was costlier than any benefits that may be derived from retaining potential migrants in situ.

As a consequence of men's migration, the Project's workforce consisted mainly of women, remunerated in food for work. Food rations were worth less than the national minimum salary. ${ }^{76}$ Therefore, food for work was justified as self-targeting: The poorest people who lacked better income opportunities strove to be employed on Project worksites to access food rations and avoid exposure to famine. In the years of maximum Project activity, the number of worksites in the dry season reached forty to fifty reforestation worksites and ten to fifteen roads/hydraulic infrastructure worksites open at the same time, for a total of up to four to five thousand people per day working for the Project. ${ }^{77}$ Project works were stopped, or substantially decreased, in the rainy season, when the majority of male migrants returned to work in their fields together with all family members, including women and children. They left again after the harvest, around October. In many Ader households harvests varied substantially from year to year. In average years subsistence production was in deficit. Migrants' earnings and food rations, when available, were used to complement consumption. ${ }^{78}$

Poor women contributed about twelve million working days to the Project's worksites between 1984 and 2000 (Figs. 4 and 5). ${ }^{79}$ Women workers on the Keita Project's antidesertification worksites became national and international icons: The Femme de Keita symbolized both the woman of national participatory populism and the woman of international aid narratives. President Kountché visited the Project in June of 1986 and decorated three women. In a public statement released after his visit, he declared:

[W] hat has moved me most and encouraged me to persist in our philosophical concept of the Société de Développement has been the participation of women. Carrying a child on their backs, with a shovel in their hands, working with rudimentary tools built for drawing the outline of reforestation trenches on the ground, they work for the soil's recuperation and rehabilitation. ${ }^{80}$

The women who participated most enthusiastically in the worksites lived in villages located on the least productive land. They embraced "worksite work" (Hausa: aikin gandari). On the worksites there was a minimal differentiation of tasks, which varied slightly with the type of worksite. Women and youths accomplished the least specialized tasks, such as carrying stones to fill gabion weir structures and digging reforestation trenches. By contrast, adult men's functions required 


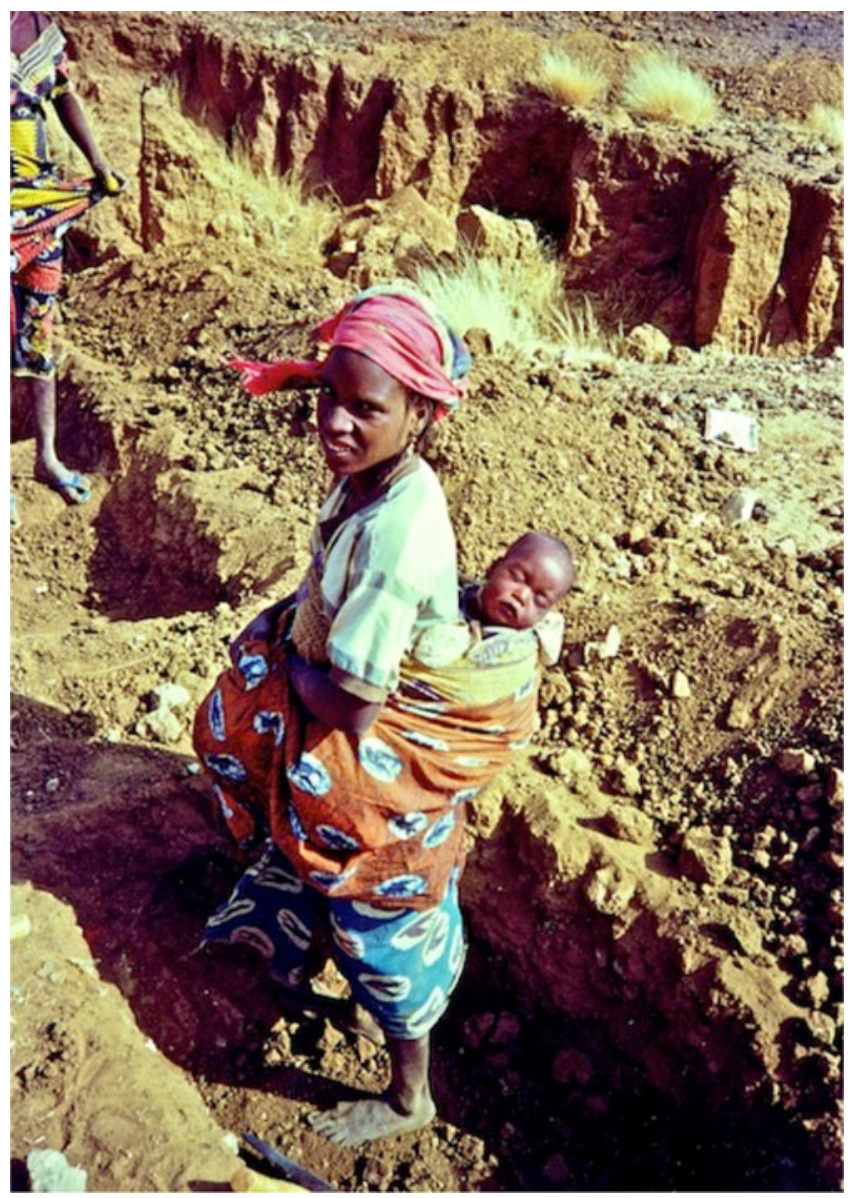

Figure 4. Femme de Keita building a reforestation trench.

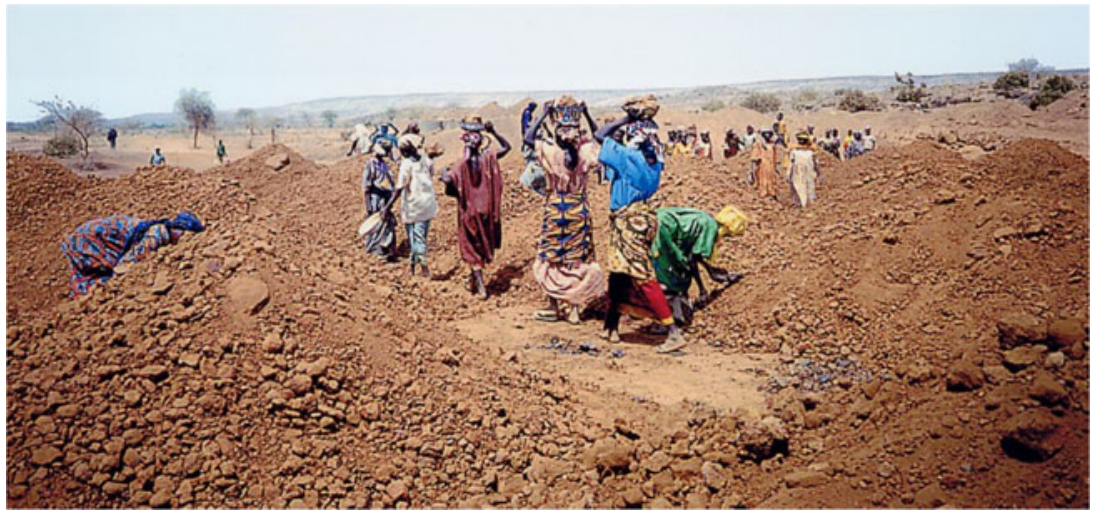

Figure 5. Femmes de Keita on the reforestation worksites. 
technical skills-electricians, mechanics, drivers (Fig. 6), skilled workers who confected and positioned gabion weirs, defined the shape of reforestation trenches, and assembled the parts of hydraulic structures (such as spillways, see Fig. 7)and were remunerated in cash, not in food. The worksite chief (chef de chantier or shugaban gandari), had to be a man if the majority of workers were men, or a woman if they were women. Workers had to be aged between thirteen and fifty years.

Women workers often referred to the Project simply as "work" (Hausa: aiki). During field-based research that I carried out in from 1998 to 2000, I endlessly heard poor women repeat muna son aiki (we want work), "because it is useful" (shina da amfani), "because we are happy [when we have a chance to work]" (muna jin dadi), "because it brings us food-for-work" (an banmu

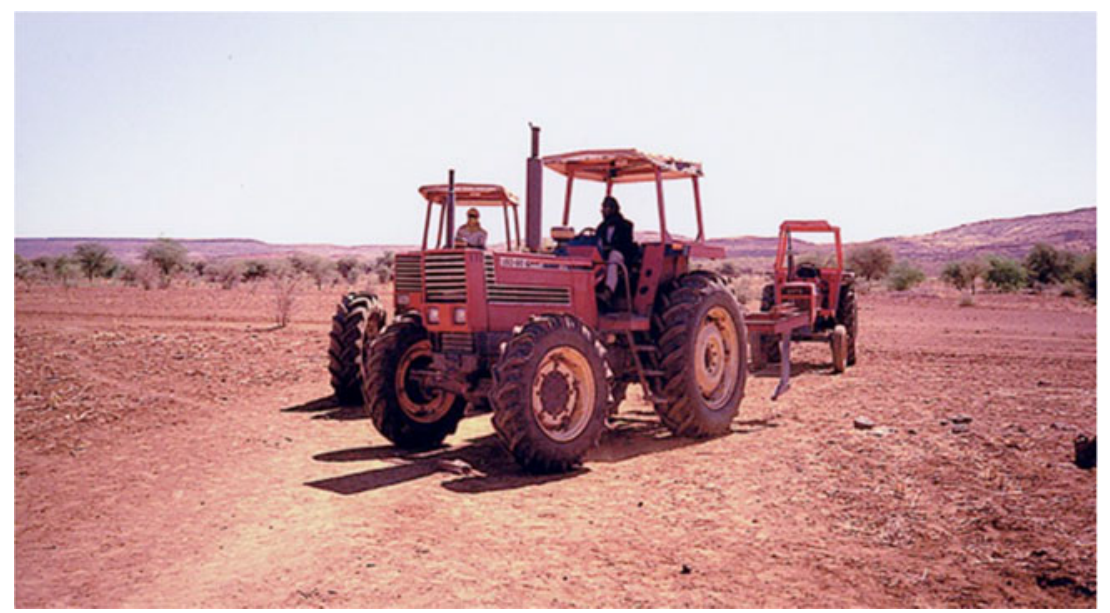

Figure 6. Tuareg tractor drivers working for the Keita Project.

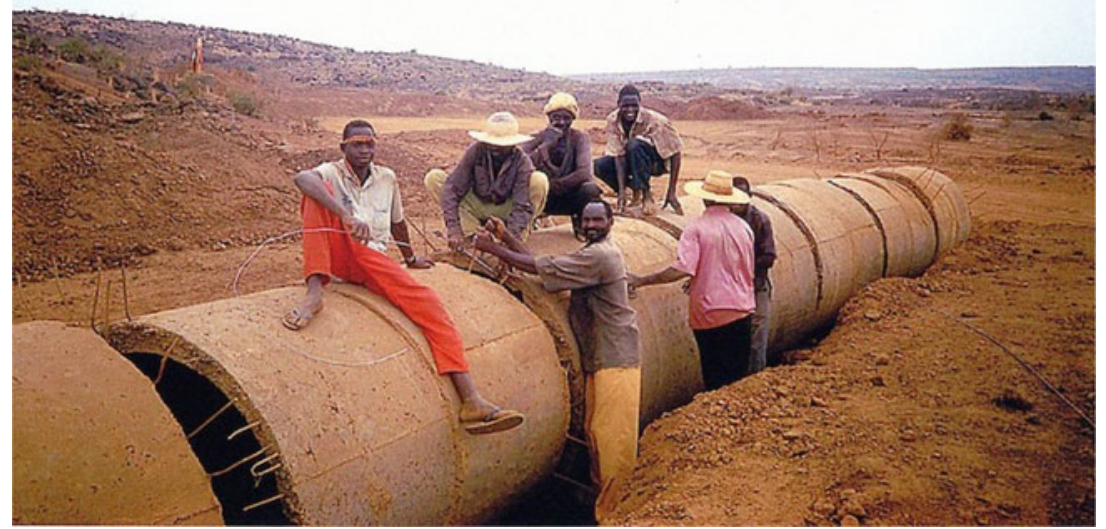

Figure 7. Spillway assemblage. 
taimako). ${ }^{81}$ The criteria followed for the opening of worksites were based on the project's environmental rehabilitation strategy. Worksites had to recruit labor from the closest villages. Women from different villages competed with each other over project works and tried to attract works to their village.

Some women of slave descent sold the tinned meat or fish included in the food ration and used the money they could save this way to ransom themselves from former masters. But in the 1980s and 1990s it was often men who paid to obtain certificates of ransom for their daughters or wives even if they had not done so for themselves. In the 1990s these practices were rare. The price of ransom was about FCFA15,000 for a man and FCFA40,000-50,000 for a woman. ${ }^{82}$ This price difference reveals bias against marrying women of slave descent unless they had been formally ransomed. Husbands ransomed wives to ensure that no descendant of a former master would one day appear and claim rights over his children, especially his daughters, who could be servants or concubines. Everyone knew that any such claim was illegal. For many this knowledge sufficed to make them reject practices that had no legal justification in contemporary national and international law. But others refused to take risks. Some of the slave descendants who paid ransom in their lifetime did so because keeping good relations with former masters could turn out to be useful, even life-sparing, one day.

\section{Gender and Status: Slow Emancipation of Women of Slave Descent}

The village of Toggock, located to the north of Ibohamane, hosted about 565 inhabitants in $1987 .{ }^{83}$ It was a small hamlet of dried-mud huts surrounded by barren glacis lands, with no access to fertile valleys. Yields from farming were low and unreliable. Toggock was inhabited entirely by descendants of slaves of a powerful Tuareg maraboutic group. Until the beginning of the twentieth century, Toggock had been a rainy-season camp of seminomadic servile herders who looked after the livestock of their masters. ${ }^{84}$ If anyone died during transhumance, his/her corpse would be brought back and buried in Toggock. Progressively its population sedentarized and began to distance itself from former elites.

In the early 2000s, Toggock hosted an impoverished population whose status was perceived as being at the bottom of regional hierarchies. However within Toggock there were some relatively minor status differences: Some men had been successful labor migrants. Prevailing gender ideologies and the gendered division of labor ruled out long-distance labor migration for women. Most of the women of Toggock had worked on the project's worksites. Through this work, they had received a small income in food-for-work.

A close look at Toggock's society reveals how interlinked hierarchies of status and gender worked in rural Tahoua at the turn of the twenty-first century. In Toggock positions of responsibility were held by a group of three elderly brothers, whose father had been a slave of a man from an influential maraboutic group. One of the brothers had been Toggock's Muslim prayer leader 
(imaam). Another brother, Balil, had resided most of his life in Toggock and was Toggock's former village chief, a position that he had passed on to his son. Yet another brother, Mousa, had traveled extensively: As a young man he had worked on French colonial worksites in what he described as a form of forced labor (Hausa: aikin doli). Although he had not been paid, his testimonies betrayed a sense of pride for having contributed to building regional roads and the Tahoua airport on colonial worksites. Through this work, he had become acquainted with persons he thought of as powerful: Africans working for the colonial administration and some Frenchmen. He had worked, too, in West African cities as a seasonal migrant. His son, Mohamed, had also been a grand exodant, a successful migrant, and was the unquestioned authority on development-related issues. He had always supervised the village worksites and had close relations with Project staff. Mohammed's father compared Mohammed's work for the project, and his relations with project staff, to his own work on colonial forced labor worksites. They both thought of these activities as fruitful for their families and the village as a whole. ${ }^{85}$

In 2000 Mohammed had three wives and thirteen children (two of which were from one of his wives' previous marriage). All his children were attending, or had attended, the village school built by the Project in 1994. Mohamed owned four scarcely productive fields in which he cultivated millet and sorghum, and a fifth field, situated next to the water detention dam built by the Project, where he planted vegetables and fruit trees, watered by narrow irrigation channels. He worked alone on this field, whereas work on the other fields was carried out by household members. Mohamed owned few heads of cattle and his wives and children took care of goats and poultry at home. He occasionally worked as a tailor, a skill he had learned on the West African Coast. When he supervised Project worksites, he earned FCFA10,000 (ca \$17) per month.

Mohamed's seventeen-member household could not meet its subsistence needs through farming its own fields. The food deficit had to be met through other income-generating activities. Mohamed's wives were responsible for domestic chores and did some work on the household fields. Each one of them received a small parcel of land from Mohammed, where they cultivated sorghum, green beans, okra, and spices. Each of Mohamed's wives had worked on the project worksites for about one day per week, in different years. The oldest wife, Fatchima, wove about five mats per month, some of which she sold at local markets. The most experienced in project work was Geshtu. Before marrying Mohamed, she had been married to a poorer, now deceased, man, and she used to work on project worksites three or four days a week. With Mohamed she had been able to retain a part of what she earned by selling tinned meat from the ration. She made a small profit from this sale. But there were times when the entire WFP ration, and any other income, had to be used to meet the family's food needs.

Only relatively better-off "femmes de Keita" were able to sell part of the food-for-work rations and keep some savings. They invested this income in small-scale foodstuff sales amongst neighbors. Women also bought goats and 
bred them for when they needed cash. Women did not own or inherit land in Toggock. As part of women's promotion activities, project staff tried, in 1995, to give credit to Toggock's women association (groupement féminin) that would enable members to buy land parcels of their own. Opposition from the village male elders had been strong, and the initiative failed. The project's support for other women-focused income generating activities and microcredit operations led to tensions between Toggock's men and some project female extension workers. Eventually, Toggock's women association was dismantled. Men controlled valuable property and positions of responsibility. Any attempts to change this had been futile and had generated male backlash against women.

A moral novel written by the only teacher of Toggock's primary school provides a good example of how people in Toggock understood relations between men and women. The (male) school-teacher came originally from a different part of the country, and occasionally wrote novels and composed verses. In 1995 he shared with me a moral tale that he had written, inspired by the femme de Keita phenomenon as he had witnessed it in Toggock. The novel was entitled "la femme de Nawaglé," or "Nawaglé's wife." The protagonist, who is never mentioned by her own name but only by that of her husband, is a prototypical femme de Keita who works hard in all project activities. Her husband, Nawaglé, is a gambler and a drunk - an antihero figure in the local imaginary. The story exalts the moral virtue of Nawaglés wife who, faced with disaster brought about by Nawaglé's debauchery, surrenders all her earnings to him, and in doing so saves her family and redeems his soul. Women's role was seen as complementary and subordinate to that of men. Although women contributed to farming and carried out some independent income-generating activities, they had access to fewer income generating opportunities than men. Women did not own valuable productive resources and did not hold positions of political authority. Their work for the project was explained as a consequence of poverty, and something that their husbands should not allow if they had sufficient economic resources to seclude their wives.

Wife seclusion (purdah) was rare in extremely poor and marginal villages like Toggock, but it sometimes happened. While Mohammed's wives had worked on the Project's worksites, Fatimata, the wife of Mohammed's classificatory brother, who was also the village chief, came from a different village and was secluded. She lived under the watchful eye of her mother-in-law. In the first years of her marriage, when the project still had worksites near Toggock, Fatimata used to say that she wished to work on the worksites. Her mother-in-law scolded her gently and called her a silly girl who did not appreciate her restful life in the shade, as opposed to digging trenches under the scorching sun. Fatimata's first child, a girl, died from the complications of undernourishment when she was only six months old. The last time I visited Fatimata in 2008 she had two children and seemed content with her life. Her seclusion attested to the relatively higher status of her husband in Toggock. 
The Keita Project had stopped its worksites, and Toggock's men and women regretted the Project's end.

There are many villages like Toggock in rural Tahoua. The inhabitants of these poor hamlets share a low status from a regional perspective, even though some men rank slightly higher than others, mainly because of their public functions in the village and/or individual success. Unlike elite women in wealthy households, with very few exceptions women in such villages aren't secluded. This is partly due to the pervasiveness of male labor migration, which leaves adult women and children in charge of farming. While in the colonial period European gendered ideas about work meant that men only were recruited as forced labor and into the second military contingent, the Keita Project for the first time allowed women to work on its worksites. Since this work was seen as a local contribution to development, workers were not paid a wage but remunerated in daily food rations.

Following the abolition of forced labor, men of slave descent resisted recruitment in the most exploitative jobs and instead took up better paid jobs abroad as labor migrants. This option was not available for female slave descendants, who were available to work in the Project's worksites. The slow death of slavery modified status hierarchies and enabled economic mobility of former slaves, men in particular. Gender hierarchies restricted women's ability to share the benefits of emancipation. This is not only due to the gendered division of labor and the income inequalities it produced. Paying ransom to buy free status was seen as more necessary for women than for men, as reflected by the former's higher ransom price. Ransom mattered less for men because men had more diversified livelihood options and greater control over their own mobility and could therefore resist the claims of erstwhile masters more effectively. By contrast, it mattered more for women because women's livelihood and mobility options were limited; furthermore, women who had not been ransomed would give birth to children whom different categories of men-husbands and former masterscould lay claim.

Unmarried women of slave descent and their fathers had an incentive to pay ransom because this made them more desirable as wives. Had ransom not been paid before marriage, a husband would ransom his wife in order to avoid competing with a potential former master over his children and the resources that these children could yield in the future. A father of slave descent had the right to receive bridewealth from the lineage of his daughter's potential groom. But had his wife not been ransomed, a descendant of his wife's (or wife's mother's) former owner may instead expect that a future "husband" make a payment to him (differently interpreted as sale price or ransom price) as legitimate owner of the girl, rather than to the girl's biological father. Men's claims over women's fertility contributed to the slower process of emancipation for women than for men. Multiple factors marginalized women, as slaves and as women. The result is that for these marginal women project work was not only tolerable, but desirable. 


\section{Migrations and Remittances}

Certain types of migration are practiced by both men and women, while others (long-distance labor migration) are seen as men's prerogative. In northern Ader people distinguish between two main types of migrants, long-distance international migrants (yan bida) and migrants who engage in regional short-cycle migrations, or masu cin rani. Cin rani or "eating the dry season" refers primarily to a small-scale movement from villages in Ader's countryside to larger centers like Tahoua, Konni, Madaoua, Keita, Tamaske, and Ibohamane. It is practiced by men and women alike, and often married couples engage in cin rani with their children. Masu cin rani produce meager harvests on their villages' scarcely productive lands and leave their homes after filling up their granaries. ${ }^{86}$ They return home before the beginning of the rains to prepare their lands for a new farming season, when the price of cereals is at its highest. Then, they draw on their own reserves and do not depend on bought food. This type of migration is seen as food-focused, rather than cash-focused: In the months migrants spend away from their village, they eat elsewhere and do not consume their own cereal stocks.

Through cin rani, entire families move and build temporary huts at the outskirts of towns where men take up casual jobs. Wives work as domestic servants in households that can afford to feed them (Fig. 8). Their day begins at 7:00 in the morning. They work until noon, when they receive a meal and take some rest. In the afternoon they prepare the evening meal for their employer's household, and receive a second meal. They go back to their temporary huts to rejoin their husband and children around 4:00-5:00 p.m. In 2005 they were paid FCFA2,000-2,500 per month (about £2.5-3). In the dry season, the periphery of Ader's largest villages is filled with the huts of masu cin rani. Not far from these are the tents of herders temporarily pitched in marginal stretches of bush between villages until the beginning of the rains, when they take their herds northwards toward the Azawagh for the salt cure.

Nowadays, long distance labor migration (bida) tends to last more than one year. International labor migrants are almost exclusively men, unmarried or leaving their wives, children, and other relatives back home (Fig. 9). The main objective of bida is to earn cash. The potential benefits of farming are not high enough to pull back migrants in the rainy season. If until the 1990s remittances were mostly entrusted to fellow migrants returning home, or sent via specialized agents offering courier services for a fee (like the drivers of the main transport networks), in the last few years Western Union has become a major player in this field. Private operators established at various migration destinations collect remittances from migrants for a fee, and send them via Western Union to their partners operating in the region of origin of the migrants. These operators are often local traders who regularly visit larger towns that host Western Union branches to replenish stocks for their village shops. When they return to the village they distribute the specified amount to the recipients indicated by the migrant. 
Remittances play a major economic role. In 2006 only four official Western Union operators in the city of Tahoua transferred more than 10 billion FCFA (about US $\$ 20$ million at the time) from various West African cities to Tahoua. ${ }^{87}$ This is a small fraction of the volume of migrant remittances sent to

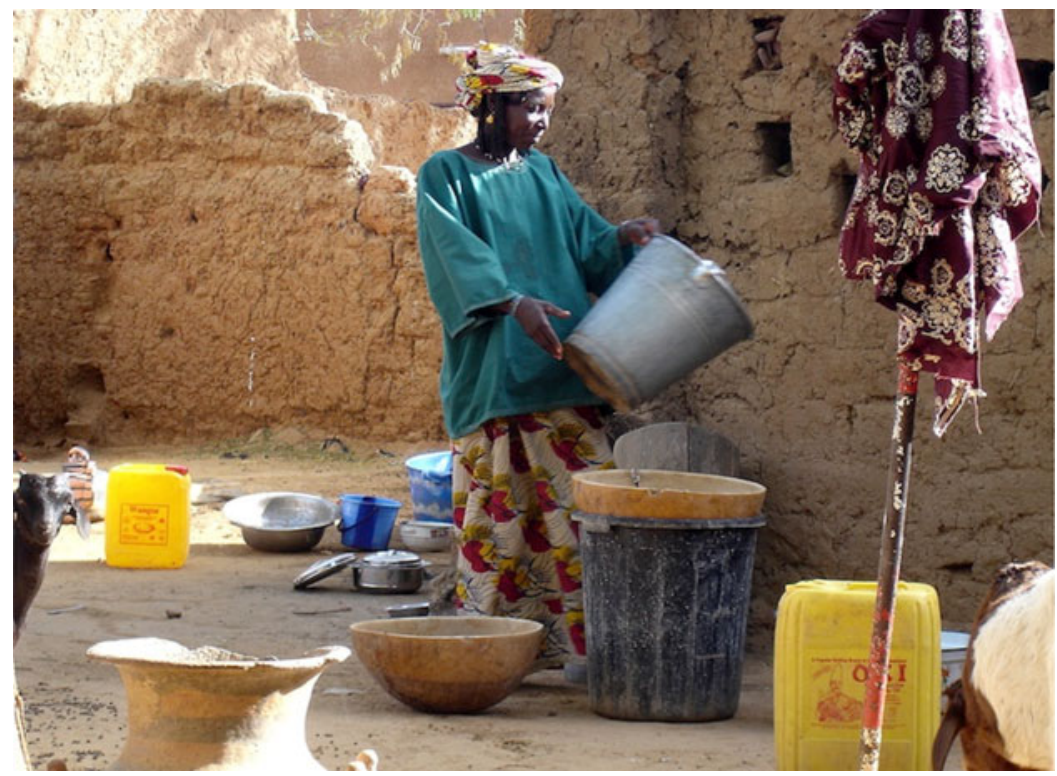

Figure 8. Woman in cin rani.

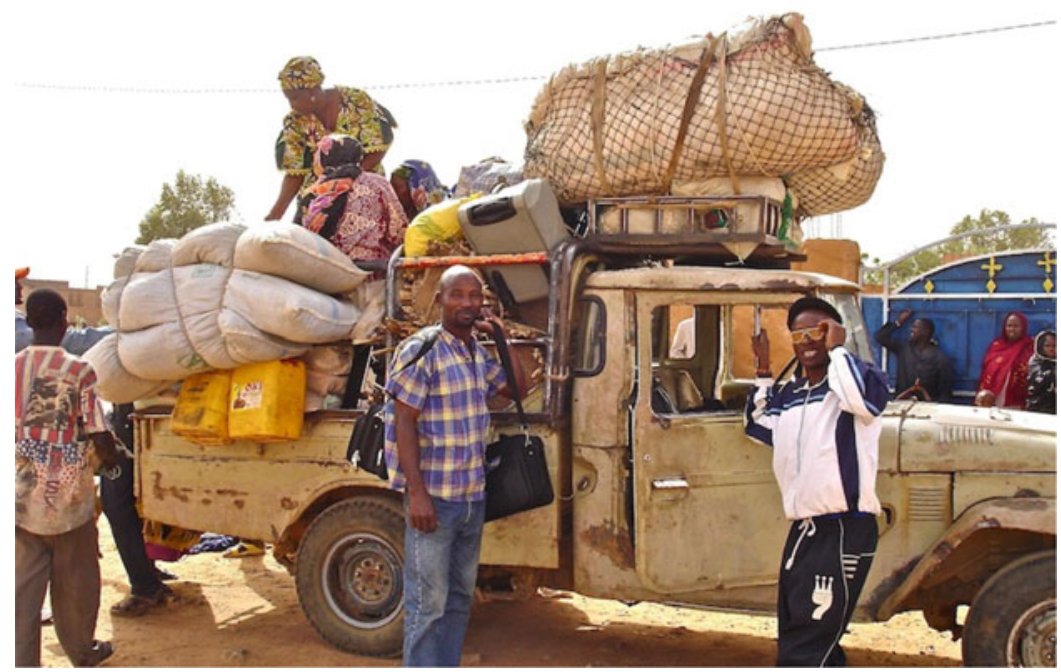

Figure 9. Labor migrants (yan bida). 
Tahoua, as it includes only some of the existing official operators in town, and only one means of money transfer amongst many. In Tahoua's administrative region, almost every rural village hosts private operators who provide money transfer services. The three main money-transfer agencies in the town of Keita alone (capital of the Keita Department, where Keita, Ibohamane, and Tamaske are located) received between FCFA15 million and 38 million/ month over the previous six months from migrants in the Ivory Coast, Cameroon, Congo, Gabon, and Libya, or approximately between FCFA180 and 456 million/year (US\$360,000-906,000). ${ }^{88}$ By contrast, the Keita Project's total budget for the period 1984-1999 had been US\$63.5 million.

\section{Conclusion}

After the abolition of forced labor, developmentalism made it possible for the colonial administration to continue to mobilize labor at a low cost, even though slavery and forced labor had become politically impracticable. Paying wages was seemingly never an option: Ader did not yield products of sufficient economic value to justify sizeable public investments. Ader was politically marginal, too: containing the discontent of potential voters in this region was never a pressing issue in Paris or Niamey. In these circumstances, employers did not offer remuneration competitive with the financial rewards that migrants could obtain abroad.

Those wishing to hire workers had to exercise a degree of coercion, or select workers who-for some reason-could not migrate. Local gender ideologies limited substantially women's ability to participate in long-distance labor migration or compete with men over the most lucrative local activities (the main trade networks, or "technical" jobs for the project). Poor women were offered meals for their work. Since the alternative was hunger, they embraced this opportunity. Emancipation had made it possible for men of slave descent to travel to locations where jobs were available. These emancipatory trajectories had been closed to women by the patriarchal ideas prevalent in Ader. Emancipation from slavery happened alongside the feminization of poverty. These dynamics, coupled to kinship and marriage systems that gave men control over women's reproductive potential, resulted in the continued subordination of women of slave descent as wives, mothers, former slaves, and laborers. Legacies of slavery and patriarchy slowed down women's emancipation.

In 2000, project staff salaries were the largest item in the project's budget. Salaries varied from the National Project Coordinator's salary (about $\$ 1,500$ / month); to the national Division Chiefs' salaries (about $\$ 1,000 /$ month), to the salaries of women extension workers (about $\$ 120 /$ month), to those of various categories of drivers (between about $\$ 120$ and $\$ 150 /$ month). ${ }^{89}$ Environmental rehabilitation worksites had been reduced to a minimum. The World Food Program's daily ration's cash value was $\$ 0.86$. The daily wage of the National Project Director was about 50 times higher than the daily monetary value of 
food rations given to the femmes de Keita. In the World Food Program's official discourse the food-for-work allowance was not considered a salary - but a symbolic contribution to acknowledge local "human investment" in their own development. Yet it was undeniably understood by the workers themselves as payment for a day's work. Other workers in other regions might have resisted these developments. But Ader's impoverished women valued food-for-work because they had few, if any, alternatives. By recasting labor as participation, developmentalism shifted attention away from the problem of rural unemployment and the value of different types of work.

The discourse of desertification emphasized the potential economic selfsufficiency of bounded regions rather than regional connectivity. The long-term capacity of this approach to confront ecological challenges at the desert's edge is questionable. Local strategies have continued to rely primarily on movement: it is mainly thanks to migrants' remittances that the region supports its high population growth rates. If throughout the twentieth century male slave descendants started migrating on their own account, most women of slave descent lacked this option. Women's contribution on the development worksites was made invisible as work; instead, it was redefined as participation in "development."

\section{NOTES}

1. This article presents in a revised, updated, and condensed form findings and ideas published in my book From Slavery to Aid: Politics, Labour, and Ecology in the Nigerien Sahel, 1800-2000 (Cambridge and New York: Cambridge University Press, 2015). I wish to thank ILWCH's senior editors, the anonymous reviewers, and the authors of the other articles in this special issue for their helpful comments. All remaining errors are my own.

2. Boubou Hama, L'exode rural: un problème de fond (Niamey, 1969).

3. Frederick Cooper, "Modernizing Bureaucrats, Backward Africans, and the Development Concept," in International Development and the Social Sciences: Essays on the History and Politics of Knowledge, ed. F. Cooper and R. Packard (Berkeley, CA, 1997), 64-92.

4. For a review of different waves of critique of developmentalism and its economic policies, see Joseph Morgan Hodge, "Writing the History of Development (Part 1: The First Wave)," Humanity 6 (2015): 432-437.

5. Historians Frederick Cooper and Monica van Beusekom focused, respectively, on political negotiations and grassroots dynamics: Frederick Cooper, "Modernizing Bureaucrats," 64; Frederick Cooper, Africa Since 1940: The Past of the Present (Cambridge, 2002), 44; Monika van Beusekom, Negotiating Development: African Farmers and Colonial Experts at the Office du Niger, 1920-1960 (Portsmouth, 2002). Political scientist Jean-Francois Bayart had advanced a similar argument, which focused primarily on the role of African political elites in the entrenchment of a discourse of dependence from which they could gain major benefits, Jean-Francois Bayart, "Africa in the world: a strategy of extraversion," African Affairs 99/30 (2000): 217-267. Anthropologists of development focused on the strategies of African villagers and aid workers and their attempts to attract and control aid revenues: Thomas Bierschenk, Jean Pierre Chauveau, Jean Pierre Olivier de Sardan, eds., Courtiers en Développement: Les Villages Africains en Quête de Projets (Paris, 2000); Thomas Bierschenk, "Development Projects as Arenas of Negotiation for Strategic Groups. A Case Study from Benin," Sociologia Ruralis 28 (1988): 146-160; Philippe Lavigne Delville, Aide internationale et sociétés civiles au Niger (Paris, 2015).

6. Michael Mortimore, Adapting to Drought: Farmers, Famine, and Desertification in West Africa (Cambridge, 1989), 218-229; Thomas Painter, Migrations, Social Reproduction and 
Development in Africa: Critical Notes from a Case Study in the West African Sahel (Milton Keynes, 1987), 21-26; Robert Charlick, Niger: Personal Rule and Survival in the Sahel (Boulder, 1991), 125-127.

7. Gareth Austin, "Cash Crops and Freedom: Export Agriculture and the Decline of Slavery in Colonial West Africa," International Review of Social History 54 (2009): 1-37.

8. Fernand Braudel, Les Ambitions de l'histoire (Paris, 1997), 60.

9. Lydon, Ghislaine, On Trans-Saharan Trails (Cambridge, 2009), 4-7; Bruce Hall, $A$ History of Race in Muslim West Africa (Cambridge, 2011), 27-69; John Hunwick, "A Region of the Mind: Medieval Arab Views of African Geography and Ethnography and their Legacy," Sudanic Africa 16 (2005): 103-136.

10. See, for example, Lecocq, Baz, Disputed Desert (Leiden: Brill, 2006), 87-93; Pierre Bernus, "Les Touaregs et les Autres," in A la croisée des études libyco-berbères: mélanges offerts à P. Galand-Pernet et L. Galand, ed. J. Drouin and A. Roth (Paris, 1993).

11. Vincent Bonnecase, La pauvreté au Sahel: du savoir colonial a la mesure international (Paris, 2011), 7.

12. Gregory Mann, From Empires to NGOs in the West African Sahel: The Road to Nongovernmentality (Cambridge, 2015), 11.

13. Claude Meillassoux, "Development or Exploitation: Is the Sahel Famine Good Business?" Review of African Political Economy 1 (1974): 27-33; Michael Watts, Silent Violence: Food, Famine and Peasantry in Northern Nigeria (Berkeley, CA, 1983).

14. James Webb, Desert Frontier: Ecological and Economic Change along the Western Sahara, 1600-1850 (Madison, WI 1995).

15. See Marie Monimart: “[M]ale migration is largely perceived as a direct consequence of desertification. Women are abandoned for months if not years. Above all, this is the most destructive phenomenon of desertification," Femmes du Sahel. La Désertification au Quotidien (Paris, 1989), 11; see also Rosalind David, Changing Places? Women, Resource Management and Migration in the Sahel (London, 1995), 6, 18-20.

16. Pierre Bourdieu, "The Forms of Capital," in Handbook of Theory and Research for the Sociology of Education, ed. J. Richardson (New York, 1986), 241.

17. I discuss reports, court cases, and witness testimonies in "Periodizing the End of Slavery: Colonial Law, the League of Nations, and Slave Resistance in the Nigerien Sahel, 1920s-1930s," submitted to Les Annales.

18. Benedetta Rossi, From Slavery to Aid: Politics, Labour, and Ecology in the Nigerien Sahel, 1800-2000 (Cambridge, 2015), 142-200.

19. Circular 73, Gouverneur General du Niger a Commandants de Cercles, May 7, 1947, Archives Nationales du Niger (hereafter ANN) 381.1.

20. Ibid.

21. The Chef de Subdivision Nomade was the homologue of the Commandant de Cercle in territorial subdivisions classified as "nomad," which followed different administrative structures and procedures.

22. Commandant de Cercle de Tahoua a Gouverneur Niger, Telegramme 491, 18 Aout 1947, ANN 381.1.

23. Capitain Delon, Rapport de tournée, February 11, 1948, ANN1E37.22.

24. Ibid.

25. Albert Sarrault, La mise en valeur des colonies françaises (Paris, 1923); Pierre Deloncle, L'Afrique Occidentale Française: découverte, pacification, mise en valeur (Paris, 1934). For more recent critical analyses, see Gabriel Massa, "Le développement économique," in La France d'Outre-Mer (1930-1960): témoignages d'administrateurs et de magistrats, ed. J. Cauzel (Paris, 2003), 165; Alice Conklin, A Mission to Civilize: The Republican Idea of Empire in France and West Africa, 1895-1930 (Stanford, 1997), especially Introduction and Chapter 7.

26. Commandant de Cercle (Brouin), Rapport de tournée, Mai 1943, ANN 1E28.54.

27. Frederick Cooper, Africa Since 1940: The Past of the Present (Cambridge, 2002), 38-49; Cooper, "Modernizing Bureaucrats," 64-92.

28. For example, Elève-administrateur Pujol, Rapport de tournée, 1947, ANN 1E35.32.

29. Cf. Commandant de Cercle (Vieroz), Télégramme-lettre à propos de l'aménagement des mares et des sources dans le Cercle de Tahoua, 10/27/1955, ANN 17.8.8.

30. Plan de développement économique et social 1961-1963.

31. Note de service no. 1018/SGAHA, Niamey, Mai 27, 1968, 1, Archives Régionales de Tahoua (hereafter ART) 1W14.20. 
32. Réflexions sur les options préalables à la mise en valeur de l'Ader Doutchi Majiya, 1964, N.A., 8, ART 1W6.56.

33. Conventions 28/C/66 and 41/C/66, see Opération intégrée Ader Doutchi Majiya, demande de financement FAC, 1967-1968, ART 1W13-bis; SMUH 1966, Schéma d'aménagement régional de l'Ader Doutchi Majiya, ART 1W10.30.

34. The Ader Doutchi Majiya region "derives its unity from a unique policy of economic development, hydro-agricultural intervention and concerted administrative action. It coincides neither with a natural region, nor with traditional or actual administrative sectors. It is only the existence of common problems and common development possibilities which has led to the creation of this new regional entity." Bonte, "Structure de classe," 1.

35. Réflexions sur les options préalables à la mise en valeur de l'Ader Doutchi Majiya, 1964, N.A., 1-2, ART 1W6.56.

36. Ibid., 3 .

37. Ibid.

38. Réflexions sur les options préalables à la mise en valeur de l'Ader Doutchi Majiya, ART 1W6.56.

39. Ibid., 8-9. Cf. "The hours of forced inactivity [of peasants] due to climatic constraints are a potential, but should not be over-estimated. We found it necessary to establish that unpaid labor, or labour paid below market price, could only be employed for works of scarce technical complexity and [works] whose interest would be immediately evident to the workers, such as works carried out on the land or on ... the hydraulic regime of waters that have a direct impact on their own lands," UNCC Service de la Coopération, June 1968, L'expérience des coopératives cotonnières - bilan de la première année de fonctionnement, ART 1W25.20.

40. Ibid., emphasis in the original.

41. Ibid., 9

42. In an insightful article, Neubert talks of "supply-driven demand" for development. See Dieter Neubert, "Le rôle des courtiers locaux dans le système du développement," in Courtiers en développement: les villages africains en quête de projets, ed. Thomas Bierschenk, Jean Pierre Chauveau, Jean Pierre Olivier de Sardan (Pariss, 2000), 243-259.

43. Ibid., 9, footnote 1.

44. Quatrième leçon: les Perspectives Décennales, 13, ART 1W7.18. The passage quoted is from the national Ten Years Perspectives, 348.

45. Proces verbal de la reunion du Comité de l'Ader Doutchi Majiya, Niamey, July 22, 1965, 4, ART 1W9.29.

46. Demandes complémentaires de financement, Programme FAC 1966-1967, Opération intégrée Ader Doutchi Majiya, 4 (ART 1W9.29); see also Demande de financement FAC 19681969, projet Ader Doutchi Majiya, 1 and 6 (ART 1W20.11); Demande de financement FAC, Tranche 1969-1970, Operation integré Ader Doutchi Majiya, 3 and 8 (ART 1W20.30); Demande de financement FAC 1969-1970, projet Ader Doutchi Majiya, appui aux collectivités villageoises, 1-2 (ART 1W20.30).

47. Demande de financement FAC 1969-1970, projet Ader Doutchi Majiya, appui aux collectivités villageoises, 2, ART 1W25.20.

48. Operation integré Ader Doutchi Majiya, tranche FAC 1967-1968, projet Ibohamane, ART 1W13.bis.

49. Interview with owners of perimeter lands, Ibohamane, March 1, 2005.

50. Aménagement de la plaine d'Ibohamane, demande FAC 1967-1968, fiche B2-1A, ART 1W13.bis.

51. Programme du stage de formation cadres paysans d'Ibohamane, 17-29 avril 1968, ART 1W14.20.

52. Ibid.

53. Ekaney Chimier, Enquête sur Ibohamane, 1970, ART 1W23.40.

54. Interview with Moussa Bukoci and other elders, Jiggina, December 1, 2008.

55. Benedetta Rossi, Physical and Social Mobility in Ader (Niger): Final Report for IRD-funded research project Mobilités Ouest-Africaines (MOBOUA), July 24, 2010.

56. This process is analyzed in Edmond Bernus and Pierre Bonte's 1970s ethnographic studies: Edmond Bernus, “L'Evolution Récente des Relations Entre Eleveurs et Agriculteurs en Afrique Tropicale: L'Exemple du Sahel Nigérien," Cahiers ORSTOM 11 (1974), 137-143, 31; Pierre Bonte, "Structure de Classe et Structures Sociales Chez les Kel Gress," Revue de l'Occident Musulman et de la Méditerranée 21 (1976): 142. 
57. In 1972 the UN Conference on the Human Environment in Stockholm recommended that a new specialized agency be created to deal with global environmental issues, backed by the financial support of donor countries. Later that same year, the General Assembly established the UN Environment Programme (UNEP). In 1973 the Office to Combat Desertification and Drought, or United Nations Special Sahel Office (UNSO) of the UNDP, was created in response to drought in the Sahel region. The first major international forum to discuss the topic was the United Nations Conference on Desertification (UNCOD) convened in Nairobi in 1977, which resulted in the adoption of the Plan of Action to Combat Desertification, and in the establishment of UNEP's Desertification Branch. Sahelian states affected by the 19681973 drought formed the CILSS (Permanent Inter-State Committee for Drought Control in the Sahel). Lee Macdonald, Natural Resources Development in the Sahel: The Role of the United Nations System (Tokyo, 1986).

58. Kountché died of illness on November 10, 1987, and was replaced without disruption by Colonel Ali Saibou, his closest collaborator and head of the armed forces since 1974.

59. "On this day, April 15, 1974, the Army decided to assume its responsibilities by putting an end to the regime that you know. After 15 years of rule marked by injustice, corruption, egotism and indifference toward the people whose well-being it pretended to ensure, we could not tolerate any longer the permanence of this oligarchy." Speech of April 15, 1974, Seyni Kountché, Discours et messages 15 Avril 1974-1915 Avril 1975 (Niamey, 1975).

60. Message à la Nation du 3 Aout 1974, in Kountché, Discours et messages, 55-56.

61. Formed by Decision No. 79-165 of October 29, 1979.

62. Kountché quoted in Pearl Robinson, "Grassroots Legitimation of Military Governance in Burkina Faso and Niger: The Core Contradictions," in Governance and Politics in Africa, ed. G. Hyden and M. Bratton (Boulder, CO, 1992), 160.

63. "From the concept of democracy the Development Society retained the necessity of participation. This participatory democracy, this grassroots democracy (démocratie à la base), follows the framework of the Development Councils, the supreme organ of which is the National Development Council ... When it turns its back to formal liberalism and facade pluralism, and becomes a regime of real participation, democracy can operate in the interest of the political party." Mamadou Dagra "La démocratie participative au Niger: allier l'idéal au fonctionnel," Bulletin du Comité National de Développement, No. 16 (September 1985), 13. See also "Démocratie participative, liberté d'expression et responsabilité," Bulletin du Comité National de Développement, No. 3 (1984), 14.

64. "Justice sociale et participation," Bulletin du Comité National de Développement, No. 4 (Special issue, 1984), 5.

65. "Genèse: la Société de Développement," Bulletin du Comité National de Développement, No. 1 (1984), 21. These ideas are reiterated and expanded in Section II of the Charte Nationale on the Conceptual Framework of the Development Society, see Charte Nationale (Niamey, 1987), 13.

66. “'Que mille cuvettes se remplissent'-le président du CRD de Tahoua le lieutenant colonel Tandja Mamadou reçoit le Bulletin du CND," Bulletin du Comité National de Développement 26 (1987), 20.

67. "CRD Tahoua," Bulletin du Comité National de Développement 1 (1984), 18.

68. "CRD Tahoua: présent radieux pour un mouvement coopératif éprouvé," Bulletin $d u$ Comité National de Développement 4 (1984), 47.

69. "L'heure de l'autocritique," Bulletin du Comité National de Développement 8 (1984), 28.

70. Ibid., 19.

71. "Politique de développement du CRD de Tahoua: la récupération des eaux pluviales," Bulletin du Comité National de Développement 25 (1986), 20.

72. PDR/ADM, Programme de coopération FAO/gouvernement italien. PDR/ADM: plan d'opérations, 1984a.

73. PDR/ADM, Rapport de la mission d'évaluation tripartite, 13; Lucia Cremona, Etude du Milieu: Résultats Partiels des Enquêtes Villageoises-Rapport (Rome, 1985), 37; Ibrahim Tiemogo and Ibrahim Boubacar, L'Approche Participative du Projet Intégré Keita. Keita: Rapport Provisoire FAO (Rome, 1994), 15.

74. Michael Smart, Rapport sur le Futur Rôle du PAM dans la IV Phase du Projet PDR/ ADM NER 6106 (ex Projet Keita), Niger-Rapport PAM (Rome, 2000), 2.

75. Interview with Souley Midou (former Project National Director), Niamey, March 7, 2010. 
76. The standard ration distributed in Keita in the first two Project phases consisted of the following, with equivalent values in FCFA (PDR/ADM 1997):

\begin{tabular}{lll}
\hline Millet: & $2.250 \mathrm{~kg}$ & FCFA248 \\
Sugar: & $0.050 \mathrm{~kg}$ & FCFA20 \\
Oil: & $0.075 \mathrm{~kg}$ & FCFA50 \\
Cow-peas (niébé) & $0.200 \mathrm{~kg}$ & FCFA28 \\
Tinned meat & 1 tin & FCFA83 \\
Total value: & & FCFA 429 (approximately US\$ 0.86 in 1997)
\end{tabular}

77. I am grateful to Dr. Dario Tricoli for this information. Dr Tricoli is the hydraulic engineer who oversaw the development and construction techniques of the Keita Project's water management structures.

78. Lucia Cremona, Aperçu sur les Activités Socio-économiques des Femmes de l'Arrondissement de Keita-Rapport FAO (Rome, 1986).

79. Michael Smart, Rapport sur le Futur Rôle du PAM dans la IV Phase du Projet PDR/ ADM NER 6106 (ex Projet Keita), Niger-Rapport PAM (Rome, 2000), 2.

80. Le Sahel, June 13-15, 1986, 3. Vivid commentaries on the femme de Keita were common in the press; see Le Sahel, June 16, 1986, 5; Sahel Dimanche, August 3, 1986, 7; Afrique-Asie, August 10, 1986, 16.

81. Villagers referred to food-for-work in Hausa as "taimakon abinci," literally "help in food."

82. Fieldnotes, September 7, 2005; September 8, 2005; October 8, 2005; October 27, 2005; November 26, 2008. Some persons I talked to, mostly slave descendants who had paid ransom themselves or knew of others who had paid ransom, mentioned a substantially higher ransom price. The value I recorded on November 26, 2008, for example, was 200,000 FCFA cited as the monetary value of a head of cattle, which was what the former slave owner requested to issue a ransom certificate.

83. Toggock is a pseudonym. All the names mentioned in this section are pseudonyms, too. I use pseudonyms because slave descent carries derogatory connotations in Ader's society today.

84. Interview with Mohamed and his father, March 3, 2005.

85. Mohammed and Mousa's perspectives on their status were, however, not identical. I published their testimonies verbatim and discussed intergenerational differences in (removed for the purpose of anonymization).

86. David Rain studied cin rani in Niger, but in Maradi, where he worked, this expression referred to long-distance migration, too; see David Rain, Eaters of the Dry Season: Circular Labor Migration in the West African Sahel (Boulder, 1999).

87. Abderrahmane Garba, Les transferts d'argent des migrants dans la région de Tahoua: modes, organisation et utilisation. Maîtrise de géographie, University Abdou Moumouni of Niamey (Niger), 2009.

88. These are, respectively, the smallest and largest amount received in (roughly) the previous six months by the three comptoirs together. Field notes, Keita, 2010.

89. Programme d'Activités de la Phase Transitoire January 1, 2000-September 30, 2000, Coopération Niger-Italie. The pay of international consultants, not reported in this report, would have been substantially higher. 